\title{
Inflation Dynamics in Ghana
}

\author{
Victor Osei \\ Bank of Ghana, Research Department, Special Studies Office \\ PO Box 26748, Thorpe Road, high Street, Accra, Ghana \\ Tel: 233-233-562673Ｅ-mail: victor.osei@bog.gov.gh
}

Received: March 11, 2015

Accepted: May 11, 2014

Published: May 30, 2014

doi:10.5296/ifb.v2i1.7913

URL: http://dx.doi.org/10.5296/ifb.v2i1.7913

\begin{abstract}
The study sought to investigate the key factors that influence inflation dynamics in Ghana. The study found that inflation in Ghana is determined primarily by inflation persistence, reflecting price expectations, domestic food prices, petroleum prices and exchange rate. The other determinants of inflation used in this study such as money supply and world food prices weakly affect domestic inflation. The study also recommended that anchoring inflation expectations and managing exchange rate misalignment remains key policy strategies in any effort and attempt by the monetary authorities to achieving and maintaining price stability in the country coupled with moderating the negative effects of other inflation determining factors.
\end{abstract}

Keywords: Inflation, Dynamics, Impulse response, Diagnostics, Unit root test 


\section{Background of the Study}

Recent studies have identified several factors underpinning sudden rise in inflation in developing countries, namely, external factors, internal factors, and accommodative policy in the form of exaggerate rise in money supply. External factors refer to rise in world food prices and world energy prices. The fact that most of developing countries import a considerable amount of food, a rise in world food prices is translated directly to an increase in domestic food prices. As food account for large proportion of basket of an average household in these countries, an increase in domestic food prices leads in turn to a general increase in prices. Similarly, world energy price shock, such as oil price, affect domestic prices almost instantaneously.

Internal factors generally refer to supply-side constraint, represented by agricultural shocks. Periods of drought, put upward pressure on food prices and hence on domestic price level. These shocks can also be captured by seasonal pattern in agricultural production. Dry seasons are followed rise in inflation, while inflation is subdued during raining seasons. When analysing determinants of inflation in Chad and Mali, Diouf (2007) find that average rainfall explains significantly inflation. Finally, accommodative policies, especially those followed by massive injection of money in the economy, generally put upward pressure on prices.

Empirically, the Phillips curve and the quantity theory of money are main frameworks used by economists to analyse inflation dynamics. The former is popular in analysing inflation in advanced economies, due mainly to the fact that inflation in these countries is essentially due to high aggregate demand which boosts employment. The rise in employment in turn puts pressure on wages and hence on overall price. Durevall et al. (2012) state clearly that this analysis is less likely in countries that predominantly dependent on agricultural sector with huge informal sector, and a low degree of unionisation of the labour market. In this set up, it is difficult to link the increase in aggregate demand to low unemployment and hence rise in wages. In addition, developing countries depict a strong negative relationship between business cycle and inflation. In general, an expansionary period is a result of positive shock from agricultural sector, which drives prices down.

Hence, the quantity theory of money is more appropriate in analysing dynamics of inflation in developing countries, in general, and in Ghana in particular. Like most of African countries, Ghana has experienced high inflationary periods in the past especially in the 1980s and early 1990 s, reaching a maximum of $174.1 \%$ in June of 1983 from nearly $17.7 \%$ inflation a year earlier. Ghana continued to witness high inflation until recently when inflation entered a lower-double digit of $10.2 \%$ in April 1999 and single digit for a very long time in June $2010(9.52 \%)$ due to policy shift and adoption of inflation-Targeting regime or framework which represents a sharp deviation from earlier monetary-Targeting regime. The question arises as to what are the main drivers of inflation in Ghana. This paper attempts to investigate this very empirical question using and modelling an appropriate inflation equation for Ghana.

\section{Stylised Facts: Inflation Dynamics and Trends}

\subsection{Historical Trends in Inflation}

Ghana like any other developing suffered from macroeconomic imbalances particularly in the 1980s and the early 1990s due to poor macroeconomic policies adopted during the time 
which resulted into high inflation regime, reaching a maximum of 174.1 percent in June of 1983 from nearly 17.7 percent inflation in the previous year. Ghana continued to experience high inflation until very recently when inflation entered a lower-double digit of 10.2 percent in April 1999 and single digit for a very long time in June 2010 (9.52\%) due to policy shift and adoption of inflation-Targeting regime which represents a sharp deviation from earlier monetary-Targeting regime(see Figure 1).

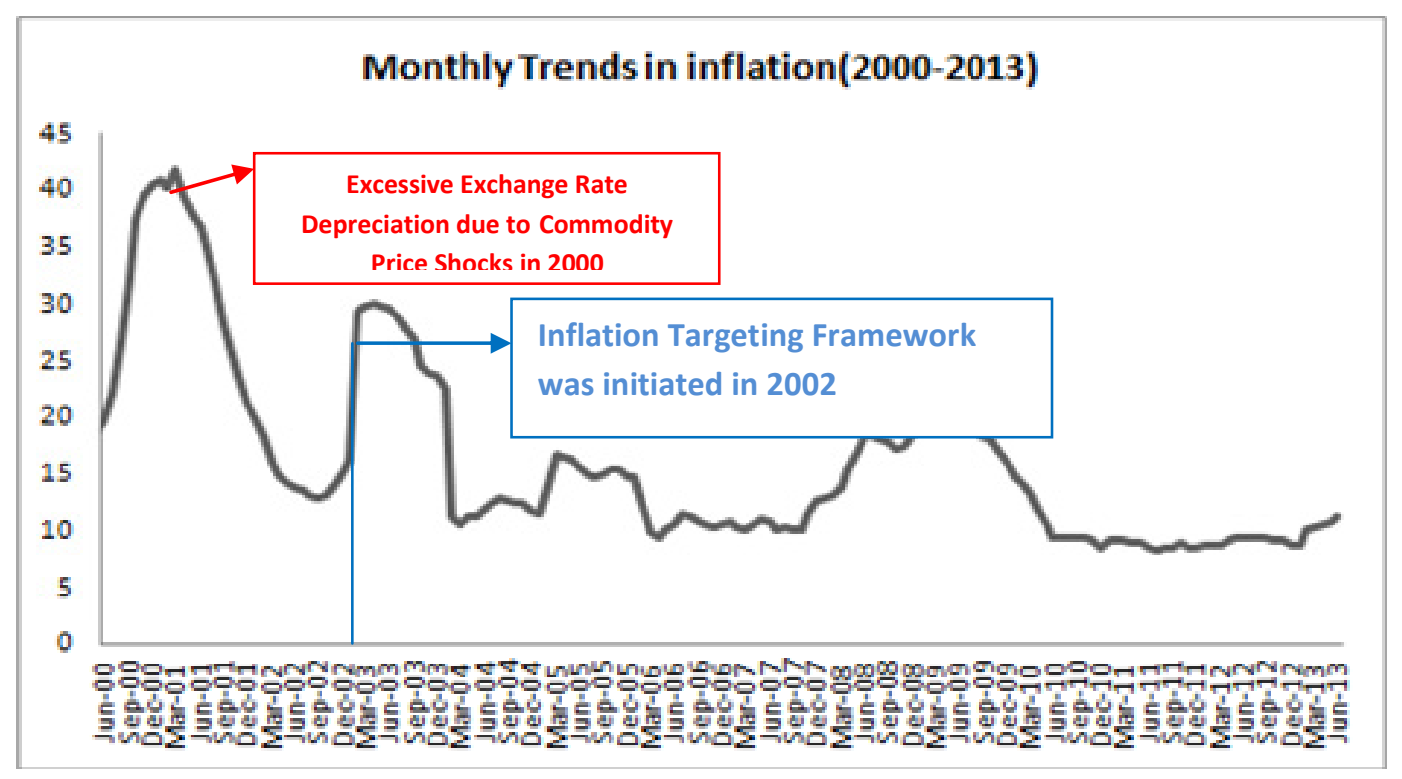

Figure 1. Trends in inflation

Since 2010, inflation in the country has trended down consistently and remained well anchored even though inflationary pressures have heightened from the beginning of 2013 which have shifted the inflation profile of the country from relatively low double-digit range $(10-12 \%)$ into relatively higher range $(15-20 \%)$ due to some well-know causes. The recent higher than expected inflation was mainly due to the upward adjustment in petroleum and utility prices announced by the Public Utility Regulatory Commission(PURC) during the second half of 2013 and the second quarter of 2014 coupled with the negative impact on inflation emanated from the exchange rate depreciation. Indeed, the country witnessed a rare period in our post - independence history of sustained relatively low inflation after adopting full fledge inflation targeting framework in 2007.

\subsection{Determinants of Inflation in Ghana: Some Graphical Analysis}

Inflation in Ghana is normally affected by changes in food and non-food prices. Most often inflation picks up faster during the learn season where food prices high than the major food season. Inflation in Ghana is determined by these factors as bumper harvest means relatively lower than expected inflation and vice-versa. On the other hand, non-food factors especially increases in crude oil prices(world energy prices) impact directly on domestic inflation through the adjustment of domestic petroleum prices and other utility prices on the Ghanaian market (see Figure 2). One other key factor that directly impact on inflation in Ghana is 
exchange rate depreciation. An unfavourable development in the exchange rate market which in turn leads to depreciation of the local currency has been identified as one of the major sources of inflation in Ghana. This suggests that maintaining exchange rate stability in Ghana remains one of the key monetary policy objectives because of its effects on price stability.

Also, as it can be inferred from Figure 2 below, excessive increases in money supply unaccompanied by improved real sector activities or increase productivities in the economy can lead to inflation, thus confirming the quantity theory of money. The influence of money supply on inflation in Ghana seems to be weak between 2000-2009 periods; however, the role of money on inflation profile in Ghana has emerged again between 2010-2014 periods as evidenced from the available data. Managing liquidity growth remains a key monetary policy tool in attempt to control inflation in Ghana by the monetary authorities.

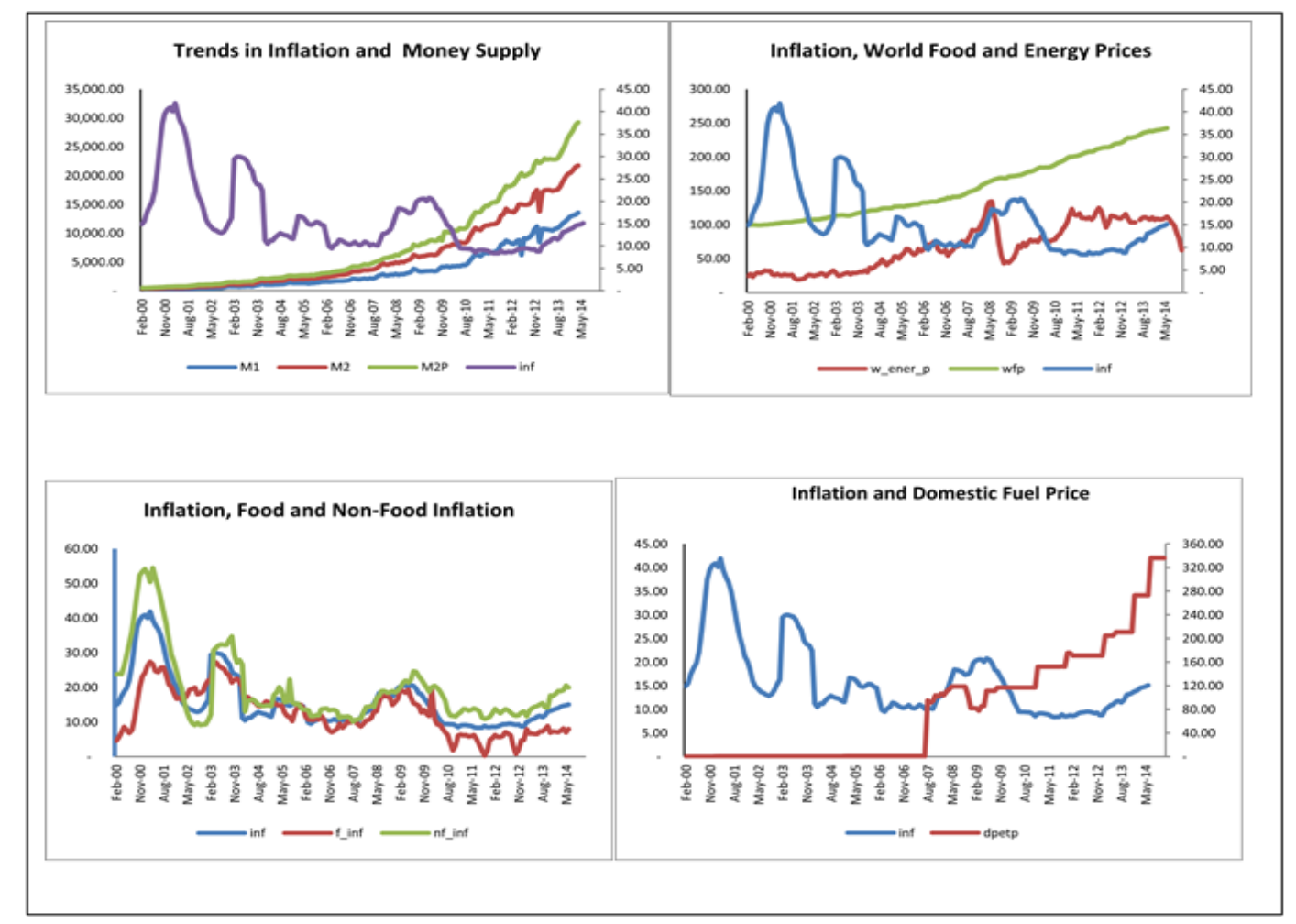

Figure 2. Determinants of inflation

\subsection{Decomposition of Inflation, Exchange Rate and Monetary Aggregates}

Figure 3 shows the characteristics of Ghana's inflation and decomposition of inflation rate. The trend component has declined progressively until July 2013 partly due to tight monetary policies and improved growth. It has started tipping up thereafter as a result of both fiscal slippage coupled with other known factors. Inflation in Ghana indicates seasonal behaviour and this seasonality can be associated with food production trends in the country (i.e. lean and major season).

As can be seen from Figure 3, the random component of inflation is mainly negative and low 


\section{Ml Macrothink}

between June 2000 and December 2000; December 2008 and May 2009 and finally between December 2012 and September 2013. This suggests that there was perhaps a break in the trend of the series. The trend has been declining since 2004 though has shown signs of trending up recently. Money and exchange rates still have some effect on the inflation dynamics although significance of the role has reduced in recent times.

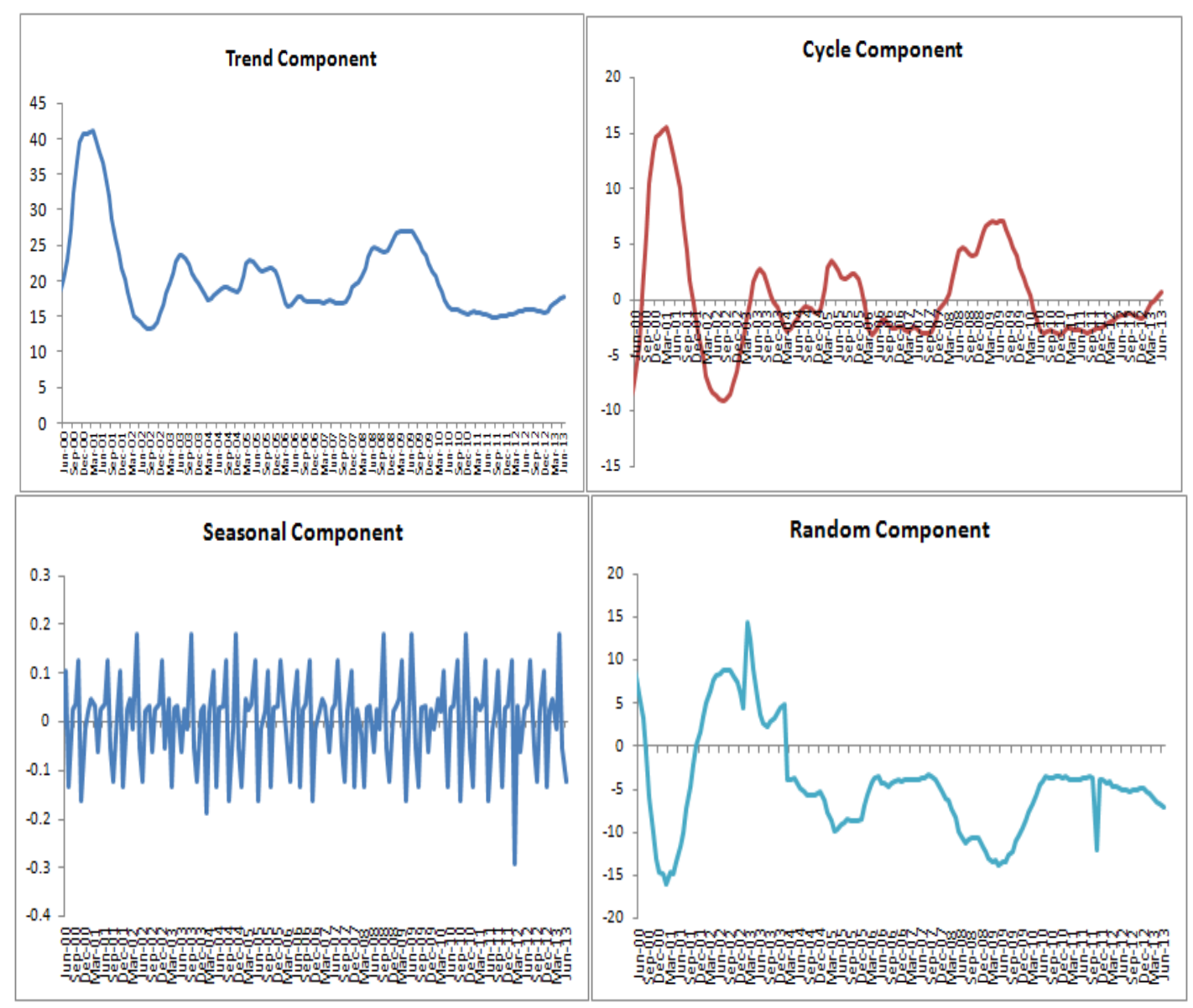

Figure 3. Monthly inflation decomposition (2000-2013)

Also, in order to assess the dynamic behaviour of exchange rate and monetary supply, as well as the possible transmission channels through which changes in these variables affect the different components of inflation, we have also decomposed these series into components using the HP filters. For monetary aggregates analysis, we have investigated three definitions of money supply: M1, M2, and M2+. Figure 4 illustrates the seasonal components of the variables in question. 

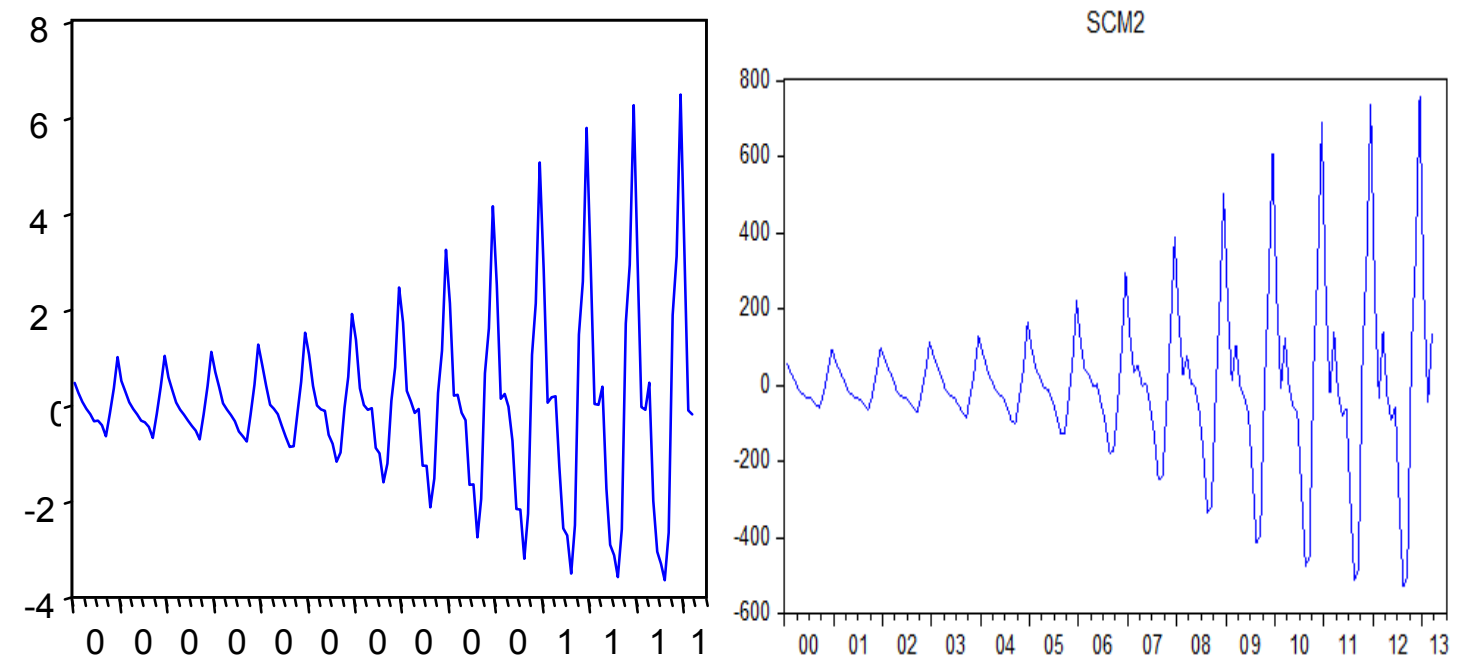

Panel A. M1 seasonal component

Panel B. M2 seasonal component
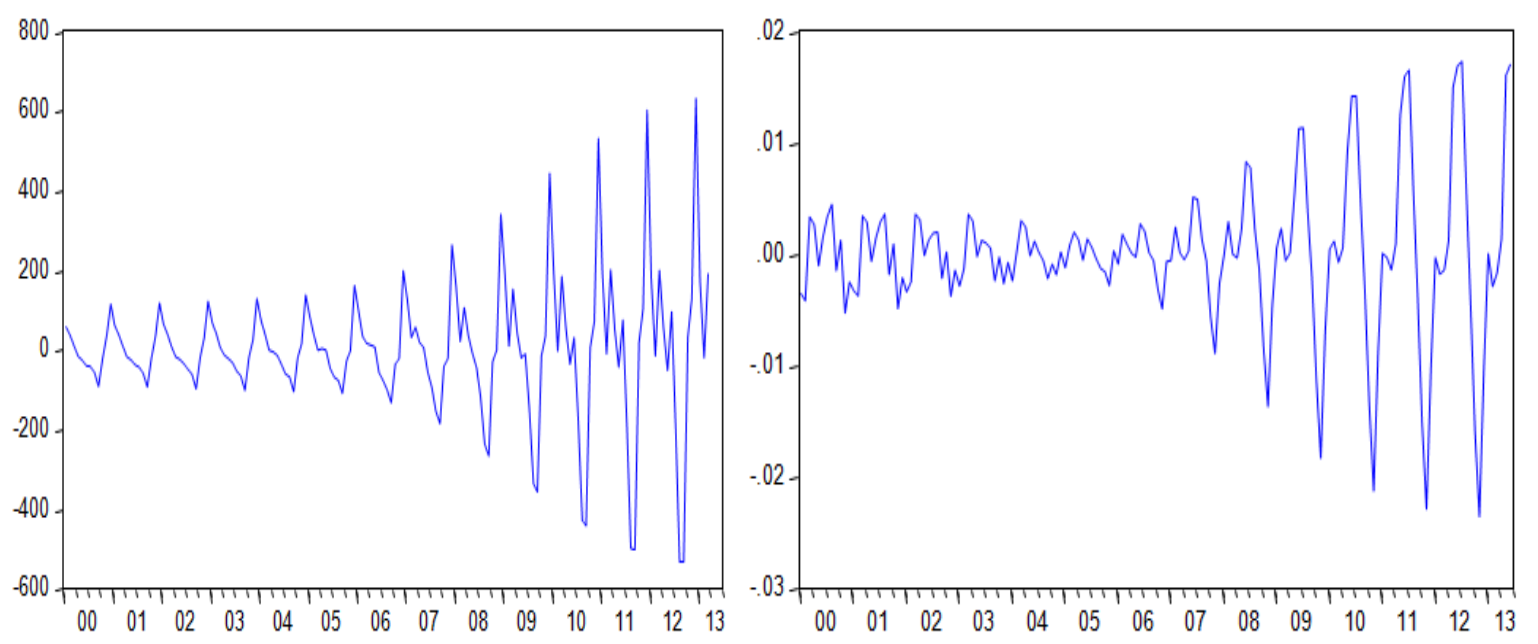

Figure 4. Monetary and exchange rate seasonal factors

\section{Theoretical and Some Empirical Literature Review}

\subsection{Theoretic Literature}

There are different schools of thought in the theoretic literature regarding what causes inflation in an economy. There is the monetarist view, Keynesian view and structuralist view.

\subsubsection{The Monetarist View}

The monetarist view asserts that changes in the general price level is caused by changes in money supply given a constant velocity of money and nominal income which is well 
specified in the famous quantity theory of money or the equation of exchange modelled below:

$$
M_{v}=P_{y}
$$

Where M equals money stock,

$\mathbf{v}$ is the velocity of money,

$\mathbf{P}$ is the general price levels,

$\mathbf{y}$ is real output.

Velocity of money or income is assumed constant while real output is also assumed constant. These two assumptions indicate that 100 per cent change in money supply will cause 100 per cent change in general price level in the economy. In other words, changes in money supply directly affect the price level in an economy like Ghana. This theory suggests that inflation is a monetary phenomenon and thus curbing inflation requires tight monetary policy (to reduce aggregate demand). The view that monetary policy should be used to curb inflation is based on three main hypotheses: in that central banks control the money supply, also money supply is an intermediate target and finally, the dichotomy between monetary and real analyses

\subsubsection{Keynesian View}

According to the Keynesians, inflation occurs when aggregate demand for final goods and services exceeds the aggregate supply at full (or nearly full) employment level. The Keynesian approach differs from the monetarist approach in the following manner. Both the monetarist and Keynesian approaches regard potential output as given with the difference that whereas in the monetarist approach, the actual output is always equal to potential output, in the Keynesian approach potential output serves only as the notional short run maximum of feasible output. Whereas in monetarist approach, excess increases in the quantity of money is responsible for increases in the price level, in the Keynesian approach, the excess increases in the total expenditure (e.g. investment expenditure and government expenditure) are the source of excess demand and hence inflation. According to the Keynesian view, any increase in aggregate demand as a result of expansion in government spending, household consumption, exports and investment will lead to higher inflation and real output will remain unchanged.

\subsubsection{The Structuralist View}

There is another important theory of inflation known as structural inflation which explains inflation in the developing-countries in a slightly different way. The Structuralists argue that increase in investment expenditure and the expansion of money supply to finance it are the only proximate and not the ultimate factors responsible for inflation in the developing countries. Structural theory of inflation has been put forward as an explanation of inflation in the developing countries especially of Latin America. The well-known economists, Myrdal and Straiten who have proposed this theory have analysed inflation in these developing countries in terms of structural features of their economies. Recently Kirkpatrick and Nixon 
have generalised this structural theory of inflation as an explanation of inflation prevailing in all developing countries.

Myrdal and Streeten have argued that it is not correct to apply the highly aggregative demand- supply model for explaining inflation in the developing countries. According to them, there is a lack of balanced integrated structure in them where substitution possibilities between consumption and production and inter-sect oral flows of resources between different sectors of the economy are not quite smooth and quick so that the inflation in them cannot be reasonably explained in terms of aggregate demand and aggregate supply.

\subsection{Some Empirical Literature}

There has been several empirical research works on inflation in Ghana and some selected studies have been review in order to fill the gap. According to a study conducted by Gyebi and Boafo (2013), which attempted to identify the macroeconomic factors responsible for inflation in Ghana for the period 1990 to 2009, the study concluded strongly that inflation in Ghana is determined by exchange rate and money supply. Also, another inflation study conducted by Lawson (1966) suggested that inflation in Ghana is affected by excessive fiscal deficits and imported inflation. This assertion confirms the monetarist hypothesis. According to an inflation study by Ahmad (1970) for the period 1960 to 1965, uncontrolled supply of money emerging from excessive government borrowing from the central bank to finance budget deficits leads to higher inflation. Again, a study conducted by Kwakye (1993) concluded that deficiency in local food production impacts negatively on inflation in Ghana. The conclusion further affirmed the structuralist view that bottlenecks in the food supply chain significantly affects inflation. He attributed this development to ever increase demand for agriculture related products due to increased population and urbanization.

Moreover, an econometric study of inflation undertook by Sowa and Kwakye (1993) modelled all the potential causes of price instability in Ghana and their result suggested that inflation is significantly determined by money supply, exchange rate, inflation expectation and supply constraints. In addition to the current literature on determinants of inflation is the work done by Chhibber and Shafik (1990), which concluded in a broader sense that inflation in Ghana strongly determined by exchange rate devaluation. Other research work on inflation in Ghana includes the studies conducted by Ewusi (1977) aimed at finding out about the determinants of price fluctuations in Ghana; Steel(1979) on hyperinflation situation in Ghana; Oti Boateng (1979) examined the inflation situation in Ghana by looking at the problems and prospects; and finally, Kwakye (1981), also conducted an econometric analysis of price behaviour in Ghana and the conclusion of his study supported the earlier researchers' views about the possible causes of inflation in Ghana.

\section{Methodology}

Most studies, such as Diouf (2007), Kinda (2011), and Davoodi et al. (2012) use the Structural VAR approach to examine inflation dynamics in Africa. The limitations of this approach can be attributed to first of all difficulty of getting relevant data for most of African countries, since these models are very sensitive to degree of freedom. Furthermore, the 
SVAR used seldom examine both long- and short-run determinants of inflation, unless one combines long- and short-term restrictions in a Structural Vector Error Correction Model (SVECM). The single-equation ECM approach will be used in this study which will enable us in identification of the equilibrium relationship and short-term dynamics in inflation. It does not have a degree-of-freedom issue encountered in other studies. The framework accommodates domestic and foreign variables, and examines equilibrium relationship of inflation while taking into account short-term dynamics.

The study follows closely the methodology proposed by Durevall et al. (2012). It will take into account both short- and long-run determinants of inflation in Ghana. Hence, the empirical strategy includes international prices, monetary aggregate, and the role of agricultural supply shock. Long-run relationships will be estimated as follows:

$$
\begin{gathered}
m-p=\delta_{1}+\delta_{2} y+\delta_{3} R \\
p n f=e+w p-\lambda_{1} \\
p f=e+w f p-\lambda_{2} \\
p^{e}=e+w p^{e}-\lambda_{3}
\end{gathered}
$$

where $m$ is the log money supply M3, $p$ is the log of the domestic price level, $y$ is the log of the real output, $R$ is the deposit rates, $p n f, p f$, and $p^{e}$ are the log of domestic non-food price, food price, and energy prices, $e$ is the log of real exchange rate, $w p, w f p$, and $w p^{e}$ are log of world non-food, food, and energy prices, and $\lambda_{1}, \lambda_{2}$, and $\lambda_{3}$, are potential trends in relative prices.

Equation 1 represents equilibrium in monetary sector. Nachega (2001) argues that money demand in Uganda can be explained by both output and exchange rate or inflation. The latter variables represent the cost of holding money. Given that the financial sector is not well-developed in Sub-Saharan Africa, both depreciation and inflation are good proxies of such a cost. Besides these four factors, supply side effects are non-negligible determinant of inflation in East Africa. We use production of cereal as a proxy of agricultural production. The long-run measure of agricultural production is obtained using its cycle component, after removing the trend.

Following, Durevall et al. (2012), we combined domestic and external factors in a single regression, which deals with both short- and long-run

$$
\begin{gathered}
\Delta p_{t}=\sum_{i=1}^{k-1} \pi_{1 i} \Delta p_{t-i}+\sum_{i=0}^{k-1} \pi_{2 i} \Delta m_{t-i}+\sum_{i=0}^{k-1} \pi_{3 i} \Delta R_{t-i}+\sum_{i=0}^{k-1} \pi_{4 i} \Delta e_{t-i}+\sum_{i=0}^{k-1} \pi_{5 i} \Delta w f p_{t-i}+\sum_{i=0}^{k-1} \pi_{6 i} \Delta w p_{t-i}+\sum_{i=0} \pi_{7 i} \Delta w p^{e}+ \\
\pi_{8} a g_{t-i}+\alpha_{1}\left(m-p-\delta_{1} y-\delta_{2} R\right)+\alpha_{2}\left(e+w p-p n f-\lambda_{1}\right)+\alpha_{3}\left(e+w f p+p f-\lambda_{2}\right)+\alpha_{4}\left(e+w p^{e}-p^{e}-\lambda_{3}\right)+ \\
\beta+v_{t}
\end{gathered}
$$




\section{Macrothink}

Where all variables are in logs, $\Delta$ is the first difference operator, and $v_{t}$ is the error term, which follows an independent and identically distributed normal distribution with zero mean and constant variance.

\section{Data Selection and Sources}

Domestic prices, the real effective exchange rate, and monetary aggregate (M1, M2 and M2+) will be obtained from the Bank of Ghana while output data will be sourced from Ghana Statistical Services (GSS). Data on world energy and food prices will be obtained from Food and Agriculture Organisation (FAO). We will also convert annual real GDP to obtain monthly series of output.

\section{Estimation Results and Discussions}

\subsection{Unit Root Test}

Firstly, it is necessary to test whether the relevant variables in equation (5) are stationary and to determine the orders of integration of the variables. To test for unit roots in the levels and first differences of the variables, a standard Augmented Dickey Fuller (ADF) and Philips-Perron Unit Root tests were performed. Table 1 and 2 indicate that the null hypothesis of a unit root in levels cannot be rejected for all of the variables at both $1 \%$ and $5 \%$ significant levels. However, the null hypotheses of a unit root in the respective variables was rejected when the variables were measured in their first differences in the standard ADF and Philips-Perron tests at 1\% level of significance except the log of real GDP which was significant at $5 \%$ in both methodologies. All the variables were integrated at order one, i.e. $\mathrm{I}(1)$.

Table 1. Standard ADF and Phillips-Peron unit root tests

\begin{tabular}{|l|c|l|l|l|}
\hline \multirow{2}{*}{ Variables } & \multicolumn{2}{|c|}{$\begin{array}{c}\text { Augmented Dickey-Fuller } \\
\text { Test }\end{array}$} & \multicolumn{2}{c|}{ Phillips-Peron Test } \\
\cline { 2 - 5 } & \multicolumn{2}{|c|}{$\begin{array}{l}\mathbf{1}^{\text {st }} \\
\text { Difference }\end{array}$} & Levels & $\begin{array}{l}\mathbf{1}^{\text {st }} \\
\text { Difference }\end{array}$ \\
\hline INF & -2.9846 & $-7.8940^{* * *}$ & -2.4464 & $-8.7416^{* * *}$ \\
\hline LM1 & -1.2822 & $-13.804^{* * *}$ & -0.9770 & $-13.9044^{* * *}$ \\
\hline F_INF & -1.8385 & $-11.4584^{* * *}$ & -2.0134 & $-11.5161^{* * *}$ \\
\hline NF_INF & -1.6190 & $-10.2503^{* * *}$ & -2.4833 & $-10.9904^{* * *}$ \\
\hline W_ENER_P & -2.0532 & $-7.8676^{* * *}$ & -3.3821 & $-7.9294^{* * *}$ \\
\hline WFP & -2.9846 & $-8.4352^{* * *}$ & -2.9892 & $-8.9592^{* * *}$ \\
\hline W & -3.9424 & $-11.8998^{* * *}$ & -6.0442 & $-11.0364^{* * *}$ \\
\hline DPETP & 1.4308 & $-13.7154^{* * *}$ & 1.7912 & $-13.7173^{* * *}$ \\
\hline EXH & 1.4155 & $-4.7621^{* * *}$ & 2.9090 & $-4.8227^{* * *}$ \\
\hline LGDP_CIEA & -0.0203 & $-14.4335^{* * *}$ & -0.0109 & $-24.9199^{* * *}$ \\
\hline
\end{tabular}

Note. $*, * *$ and $* * *$ represent $10 \%, 5 \%$ and $1 \%$ significance levels respectively. 


\subsection{Co-Integration Test}

The Johansen Co-integration test is normally used to determine whether linear relationship between variables exist or it establishes whether there exist co-movements among some selected economic variables. The Johansen Co-integration test suggested that at least two (2) co-integration equations at the 5 per cent significant and therefore rejects the null hypothesis of no Co-integration. This is indicated by the Trace Statistics of 196.43 with benchmark critical value of 0.05 significant at the probability value of 0.0050 (See Table 2 below).

Table 2. Johansen co-integration test

\begin{tabular}{|c|c|c|c|c|}
\hline \multicolumn{2}{|l|}{ Unrestricted Cointegration Rank Test (Trace) } & 0.05 & \\
\hline Hypothesized & & Trace & Critical Value & Prob. $^{* *}$ \\
\hline No. of CE(s) & Eigenvalue & Statistic & 219.4016 & 0.0000 \\
\hline None * & 0.385630 & 275.8384 & 179.5098 & 0.0050 \\
\hline At most 1 * & 0.301604 & 196.4316 & 143.6691 & 0.1009 \\
\hline At most 2 & 0.191484 & 137.9198 & 111.7805 & 0.1529 \\
\hline At most 3 & 0.172101 & 103.2734 & 83.93712 & 0.2524 \\
\hline At most 4 & 0.118744 & 72.48852 & 60.06141 & 0.2023 \\
\hline At most 5 & 0.100455 & 51.88423 & 40.17493 & 0.1618 \\
\hline At most 6 & 0.083471 & 34.62800 & 24.27596 & 0.1420 \\
\hline At most 7 & 0.075443 & 20.42066 & 12.32090 & 0.2664 \\
\hline At most 8 & 0.036625 & 7.634923 & 4.129906 & 0.2495 \\
\hline At most 9 & 0.009482 & 1.552997 & \\
\hline Trace test indicates 2 cointegrating eqn(s) at the 0.05 level & \\
\hline$*$ denotes rejection of the hypothesis at the 0.05 level \\
\hline$* *$ MacKinnon-Haug-Michelis (1999) p-values \\
\hline$* *$ MacKinnon-Haug-Michelis (1999) p-values \\
\hline
\end{tabular}

\subsection{Lag Selection Test}

The sequential modified likelihood ratio (LR) test was carried out as follows. Starting from the maximum lag, we tested the hypothesis that the coefficients on lag $l$ are jointly zero using the Chi-square $\left(x^{2}\right)$ statistics:

$$
L R=(T-m)\left\{\log \left|\cap_{i-1}\right|-\log \left|\cap_{i}\right|\right\} \sim x^{2}\left(k^{2}\right)
$$

Where $m$ is the number of parameters per equation under the alternative. Note that we employ Sims' (1980) small sample modification which uses $(T-m)$ rather than $(\mathrm{T})$. We compared the modified LR statistics to the 5\% critical values starting from the maximum lag, and decreasing the lag one at a time until we first get a rejection. The alternative lag order from the first rejected test was marked with an asterisk (if no test rejects, the minimum lag will be marked with an asterisk). It is worth emphasizing that even though the individual tests have 
size 0.05 , the overall size of the test will not be $5 \%$. We used lag length two suggested by the Schwarz Criterion (SC) instead of eight lags as suggested by the Akaike Information Criterion (AIC) due to the relatively small sample size(see Table 3) used in the study.

Table 3. VAR lag order criteria

\begin{tabular}{|c|c|c|c|c|c|c|}
\hline \multicolumn{2}{|l|}{ Exogenous variables: C } & & & \\
\hline \multicolumn{2}{|l|}{ Included observations: 153} & & & & \\
\hline Lag & LogL & LR & FPE & AIC & SC & HQ \\
\hline 0 & -3288.443 & NA & 2515891. & 43.11691 & 43.31497 & 43.19736 \\
\hline 1 & -1453.857 & 3405.376 & 0.000358 & 20.44257 & $22.62132^{*}$ & 21.32762 \\
\hline 2 & -1258.724 & 336.7004 & $0.000105^{*}$ & 19.19900 & 23.35843 & $20.88863^{*}$ \\
\hline 3 & -1176.138 & 131.7055 & 0.000137 & 19.42664 & 25.56674 & 21.92085 \\
\hline 4 & -1097.180 & 115.5982 & 0.000195 & 19.70170 & 27.82248 & 23.00050 \\
\hline 5 & -1000.683 & 128.6625 & 0.000233 & 19.74749 & 29.84895 & 23.85087 \\
\hline 6 & -884.9820 & 139.1440 & 0.000232 & 19.54225 & 31.62439 & 24.45021 \\
\hline 7 & -767.5255 & 125.9010 & 0.000249 & 19.31406 & 33.37688 & 25.02661 \\
\hline 8 & -632.4288 & $127.1498^{*}$ & 0.000242 & $18.85528^{*}$ & 34.89877 & 25.37241 \\
\hline
\end{tabular}

\subsection{Specification of the Model}

The Figure 5 below presents inverse roots of the characteristic AR polynomial. The estimated VAR is table (stationary) if all roots have modulus less than one and lie inside the unit circle. If the VAR is not stable, certain results (such as impulse response standard errors) are not valid. There will be $k p$ roots, where $k$ is the number of endogenous variables and $p$ is the largest lag. The result suggests that all the roots have modulus less than one(1) and all lie inside the unit circle and therefore the VAR is stable and well-specified (See Figure 5).

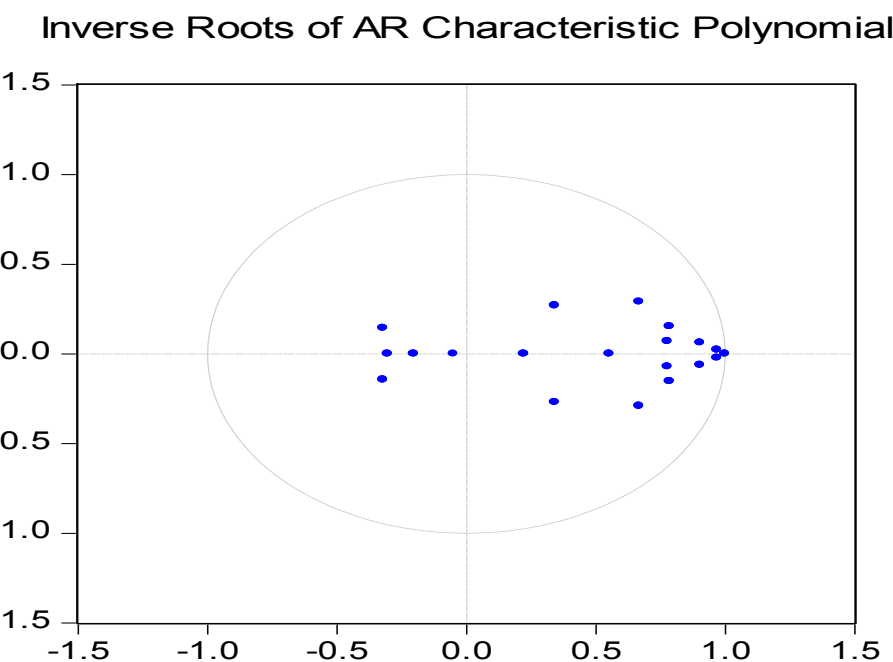

Figure 6. Inverse roots of AR polynomial 


\subsection{VAR Residual Normality and Heteroskedasticity Tests}

The residual normality test suggests that the estimated VAR model is white noise and satisfies the normality assumption Jarque-Bera statistics is significant at both 1 and 5 per cent indicated by Table 3 below. Also, the estimated VAR model passed the residual heteroskedasticity Test at both 1 and 5 per cent level of significance level (See Table $4 \& 5$ )

Table 4. VAR residual normality test

\begin{tabular}{|c|c|c|c|c|}
\hline \multicolumn{5}{|c|}{ Orthogonalization: Residual Correlation (Doornik-Hansen) } \\
\hline \multicolumn{5}{|c|}{ Null Hypothesis: residuals are multivariate normal } \\
\hline Component & Skewness & Chi-sq & df & Prob. \\
\hline 1 & 1.900139 & 52.41618 & 1 & 0.0000 \\
\hline 2 & -0.195902 & 1.125366 & 1 & 0.2888 \\
\hline 3 & -0.554251 & 8.135910 & 1 & 0.0043 \\
\hline 4 & 0.820083 & 15.94015 & 1 & 0.0001 \\
\hline 5 & 2.465064 & 70.36038 & 1 & 0.0000 \\
\hline 6 & -0.030519 & 0.027756 & 1 & 0.8677 \\
\hline 7 & -0.263954 & 2.016515 & 1 & 0.1556 \\
\hline 8 & 5.513200 & 146.5452 & 1 & 0.0000 \\
\hline 9 & 0.910416 & 18.85791 & 1 & 0.0000 \\
\hline Joint & & 315.4538 & 10 & 0.0000 \\
\hline Component & Kurtosis & Chi-sq & $\mathrm{df}$ & Prob. \\
\hline 1 & 35.97189 & 420.5303 & 1 & 0.0000 \\
\hline 2 & 3.362040 & 1.292534 & 1 & 0.2556 \\
\hline 3 & 9.141138 & 87.20873 & 1 & 0.0000 \\
\hline 4 & 9.917450 & 75.62945 & 1 & 0.0000 \\
\hline 5 & 12.37801 & 89.20154 & 1 & 0.0000 \\
\hline 6 & 3.361730 & 1.969845 & 1 & 0.1605 \\
\hline 7 & 3.559988 & 2.021070 & 1 & 0.1551 \\
\hline 8 & 45.51554 & 891.7676 & 1 & 0.0000 \\
\hline 9 & 6.563304 & 9.885530 & 1 & 0.0017 \\
\hline Joint & & 1672.224 & 10 & 0.0000 \\
\hline Component & Jarque-Bera & $\mathrm{df}$ & Prob. & \\
\hline 1 & 472.9465 & 2 & 0.0000 & \\
\hline 2 & 2.417900 & 2 & 0.2985 & \\
\hline 3 & 95.34464 & 2 & 0.0000 & \\
\hline 4 & 91.56960 & 2 & 0.0000 & \\
\hline 5 & 159.5619 & 2 & 0.0000 & \\
\hline 6 & 1.997602 & 2 & 0.3683 & \\
\hline 7 & 4.037585 & 2 & 0.1328 & \\
\hline 8 & 1038.313 & 2 & 0.0000 & \\
\hline
\end{tabular}




\begin{tabular}{|c|c|c|c|c|}
\hline 9 & 28.74344 & 2 & 0.0000 & \\
\hline Joint & 1987.678 & 20 & 0.0000 & \\
\hline
\end{tabular}

Table 5. VAR residual heteroskedasticity test

\begin{tabular}{|c|c|c|}
\hline \multicolumn{2}{|l|}{ Included observations: 165} \\
\hline Joint test: \\
\hline Chi-sq & df & Prob. \\
\hline 1818.987 & 16 & 0.0004 \\
\hline
\end{tabular}

\subsection{Impulse Responses}

The first row of chart 5 indicates the response of inflation to the random innovations of the variables in the VAR system. Random innovations in inflation have a strong positive impact on inflation in the first three months (i.e. first quarter). Also, a shock to exchange rate has a potential impact on domestic inflation in the initial period and the inflation trends upward continuously to the ninth period (i.e. roughly end of the third quarter) after the initial shock. In both cases, the significance of the responses is strong for the later periods. The impulse response graph suggests that inflation response sharply to a shock in domestic prices for a period of six months( two quarters) reflecting the first and second round effects of domestic price adjustments on inflation in Ghana. Random innovations in money supply variable seem to have weak effects on inflation as suggested by response of inflation to shocks in money supply. This could be attributed to unstable money demand function of the economy, which probably informed the central bank of Ghana to abandon the monetary targeting framework by adopting the inflation targeting monetary policy regime. However, random innovations in world food prices have no major impact on domestic inflation as shown by the impulse response graph (See Figure 6). 


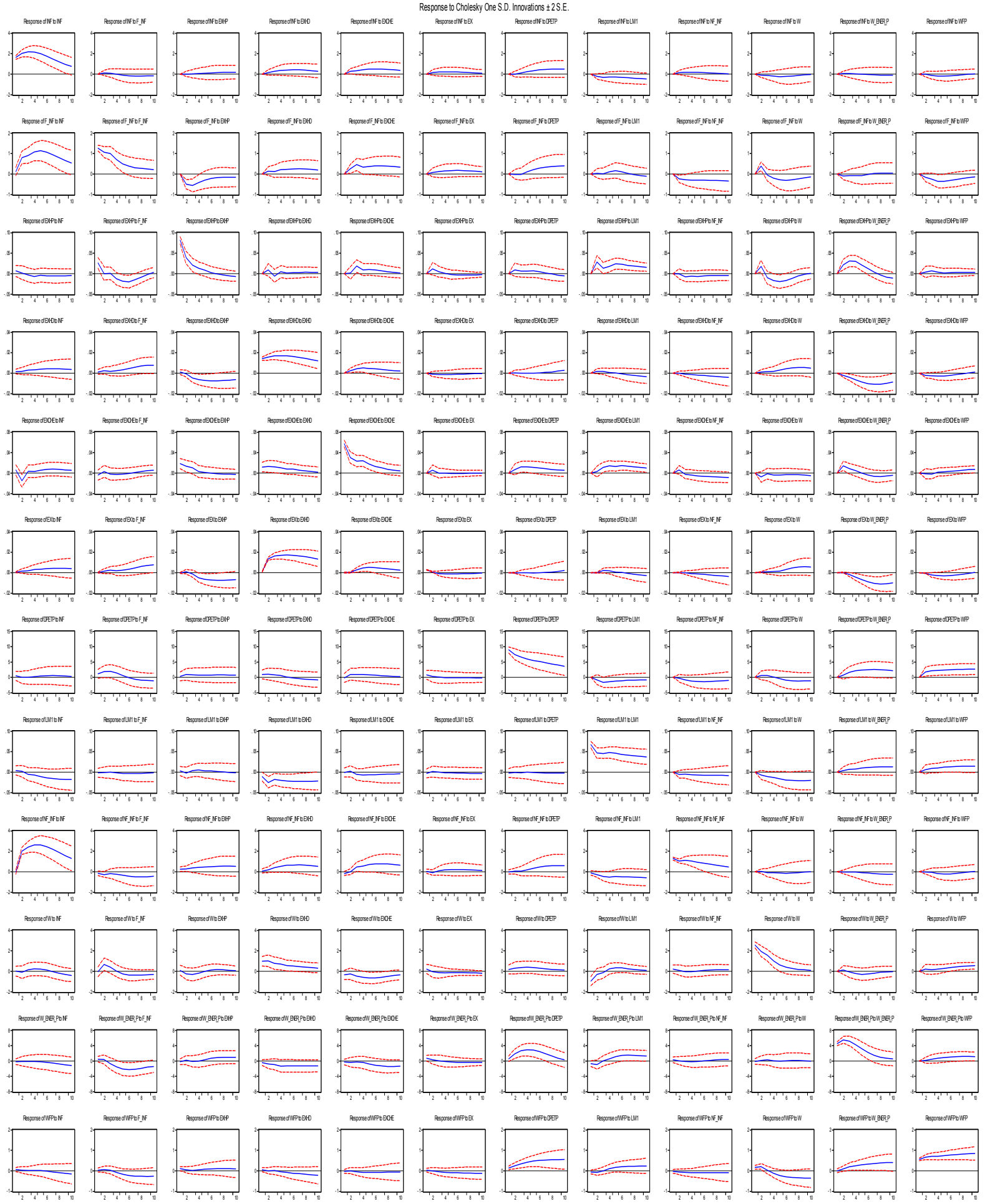

Figure 7. Impulse response graph: reaction of domestic inflation to shocks

\subsection{Variance Decomposition}

Variance decomposition gives explanations to changes in variables in a VAR system to random innovations. It provides logical reasons to the relative significance of random 
innovations to each respective variable in the VAR. For the first period, changes in inflation were 100 per cent explained by itself. During the second period, exchange rate depreciation explained 1.19 per cent changes in inflation, followed by changes in money supply(M1) $(0.79 \%)$; while innovation in inflation itself accounted for 96.75 per cent. The innovations in the other explanatory variables explained less than 5 per cent change each in inflation during the second period. The importance of the random innovations of the endogenous variables on inflation picks up over time while the innovations in inflation variable itself diminish. For the ninth period, the effects of the random innovations on inflation itself declined from 100 per cent in the first period to 83.3 per cent, while impact of innovations in exchange rate firmed up to 4.44 per cent with innovations in domestic petroleum prices and money supply, accounting for 3.19 per cent and 2.63 per cent respectively (See Table 6). The variance decomposition of inflation suggests that inflation in Ghana is strongly explained by inflation persistence based basically on inflation expectations in Ghana. Hence, managing inflation expectation by anchoring it remains key to achieving and maintaining price stability in Ghana.

Table 6. Variance decomposition

\begin{tabular}{|c|c|c|c|c|c|c|c|c|c|c|c|c|c|}
\hline 형뭄 & $\Sigma \Sigma$ & 8 & $=8$ & 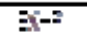 & $\Delta x$ & $30-5$ & $\equiv$ & $\mathrm{FE}=$ & $\bar{I}$ & $F_{-} F$ & 7 & IELE & $=$ \\
\hline - & $=5$ & 7989: & s.m. & 892920 & 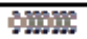 & 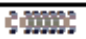 & somentip & gimpin & รั119:? & somene & $3129 m$ & 5092 & 891212 \\
\hline 2 & 2:15 & 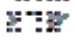 & 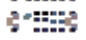 & 37Fo & '9:Es & "Tras & 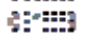 & L 358 & 9.7s: & 3 & $942 x$ & 35 & 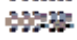 \\
\hline$\vdots$ & इ2L & $y=0$ & '):3: & 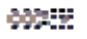 & צรW? & " & 'SEEg: & syz & "WE"? & 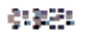 & m: & sist" & ร" \\
\hline ! & I" & 辛3 & 30 & M湿 & "g登 & ins: & 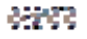 & 3:38 & "थ & 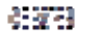 & & 3 & 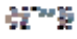 \\
\hline : & I" & zagn & รั5" & $394 z$ & " 325 & tanen & 9:3E: & צ'ב: & " 注注: & 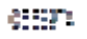 & '9:18 & sase & 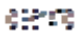 \\
\hline$\vdots$ & : $w$ & 3ะ: & STE: & MYME: & mo & इtzas & 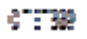 & " Iank & - כha: & y:ths & YAXY & ร.85: & $95 \%$ \\
\hline$=$ & : & 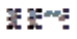 & $\sin \alpha$ & 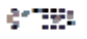 & rasen & Szy" & 5 & $-x=$ & - Ma: & 2:30 & 928 & $\sin$ & gosese \\
\hline 3 & 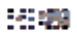 & $3 x=5$ & ร 1458: & 'צ: & trox & : & 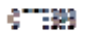 & 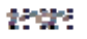 & zesma & 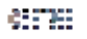 & 97: & SUE\% & ร:ב:23 \\
\hline$?$ & :73: & 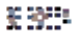 & s:32y & 3::":3 & 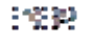 & an & & 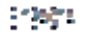 & 굴: & 3:212 & $3^{*}+2 y$ & 'มR:? & 9:5:y" \\
\hline 9 & 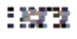 & 572 & ร: :asz: & 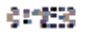 & :W:Z & sancy & 5728 & 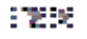 & 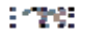 & 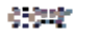 & gaxy & เงวะ & 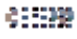 \\
\hline
\end{tabular}

\section{Conclusions and Way Forward}

The study suggested that inflation in Ghana is influenced primarily by inflation persistence reflecting price expectations, domestic food prices, petroleum prices and exchange rate. The other determinants of inflation used in this study such as money supply and world food prices weakly affect domestic inflation. The diminished role of money supply in inflation determination could be one of the potential reasons why the central bank of Ghana abandoned the monetary targeting monetary policy framework and adopted the inflation targeting monetary policy framework in July 2007. The study has shown that anchoring inflation expectations and managing exchange rate misalignment remains key policy strategies in any effort and attempt by the monetary authorities to achieving and maintaining price stability in the country coupled with moderating the negative effects of other inflation determining factors. 


\section{References}

Chhibber, A. J., \& Shafik, N. (1990). Exchange reform, parallel markets and inflation in Africa; The case of Ghana. World Bank Working Paper Series, No. 427, World Bank, Washington D.C.

Diouf, M. A. (2007). Modeling Inflation for Mali. IMF Working Paper Series W/P/07/295, Washington DC. http://dx.doi.org/10.5089/9781451868586.001

Durevall, D., \& Ndung'u, N. (2001). A dynamic model of inflation of Kenya, 1974-1996. Journal of African Economies, 10(1), 92-125. http://dx.doi.org/10.1093/jae/10.1.92

Ewusi, K. (1977). The Determinants of Price Fluctuations in Ghana. ISSER Discussion Paper, University of Ghana, Legon, December.

Gyebi, F., \& Boafo, G. K. (2013). Macroeconomic Determinants of Inflation in Ghana From 1990-2009. International Journal of Business and Social Research (IJBSR), 3(6).

Kabundi, A. (2012). Dynamics of Inflation in Uganda. AfDB Working Paper Series, No 152-August 2012.

Keynes, J. M. (1940). The Collected Writing of J.M Keynes: Activities 1940-43 and 1944-46. A Review Article by W.Salant, The Brookings Institution Journal of Economic Literature, 32, 1056-1062.

Kindal, T. (2011). Modeling Inflation in Chad. IMF Working Paper Series, WP/11/57.

Kwakye, D. K. (2012). Single-Digit Inflation and the Cost of Living Dichotomy in Ghana. Institute of Economic Affairs, 19(9).

Kwakye, J. K. (1981). An Econometric Analysis of Price Behaviour in Ghana. MSc Thesis, University of Ghana.

Lawson, R. M. (1966). Inflation In The Consumer Market In Ghana. Econometric Bulletin of Ghana, 10(1).

Nachega, J. C. (2001). Financial Liberalization, Money Demand and Inflation in Uganda. IMF Working Paper Series. No. 1/118, Washington DC. http://dx.doi.org/10.5089/9781451854084.001

Oti, B. E. (1979). Inflation In Ghana: Problems and prospects. ISSER discussion paper.

Simpasa, A., \& Gurara, D. (2011). Inflation Dynamics in selected East African countries: Ethiopia, Kenya, Tanzania and Uganda. A Brief publication by AfDB.

Sowa, N. K., \& Kwakye, J. K. (1993). Inflationary Trends and Control in Ghana. African Economic Research Consortium (AERC) Research Paper 22. Nairobi, Kenya. IEA, Ghana.

Steel, F. (1979). Hyperinflation in Ghana. Legon Observer, 308-312. 


\section{Appendix}

Appendix 1. Endogenous Variables

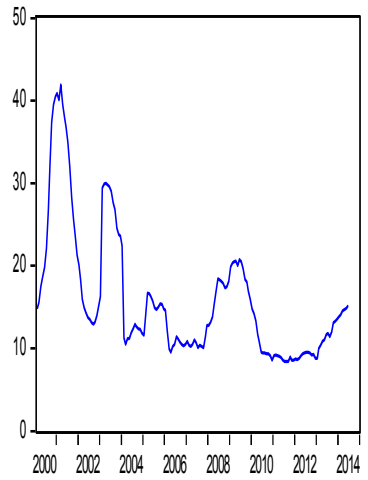

$-\mathbb{N F}$

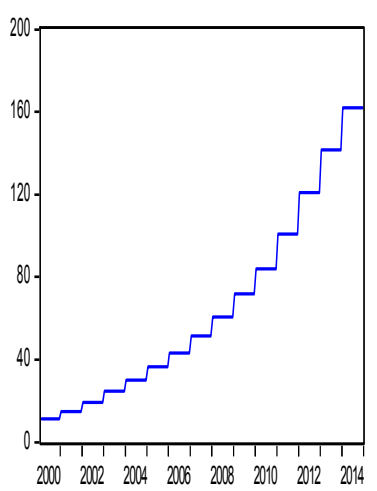

$-W$

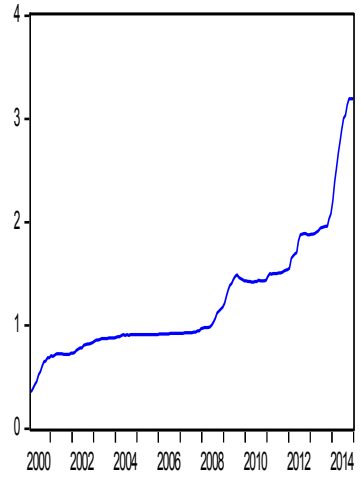

-EX

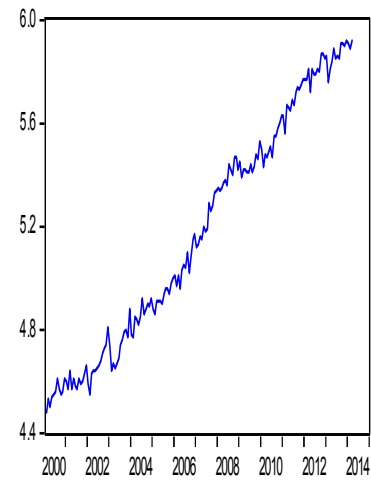

- LGDP_CEA

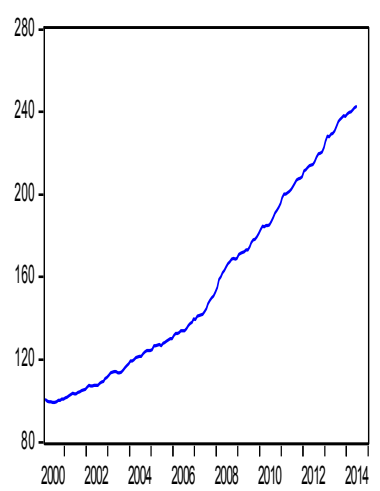

- WFP

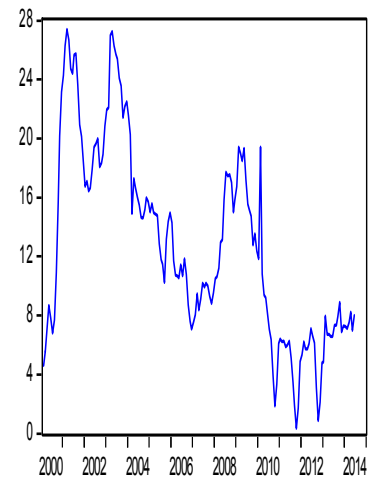

$-F$ NF

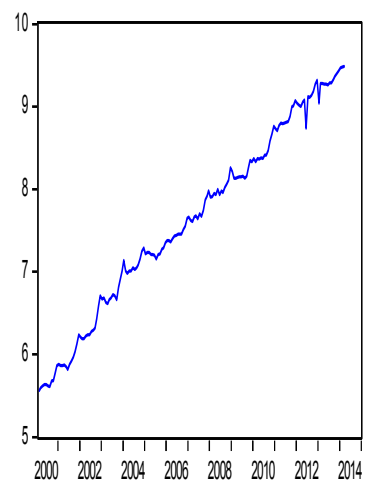

-LM1

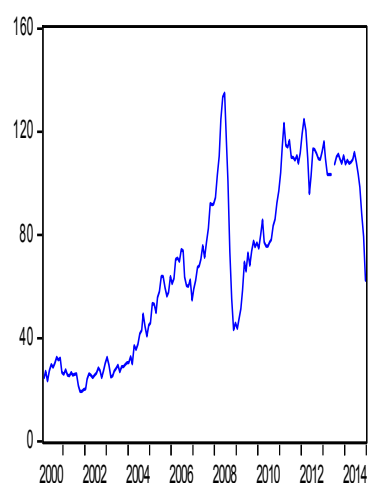

-WENERP

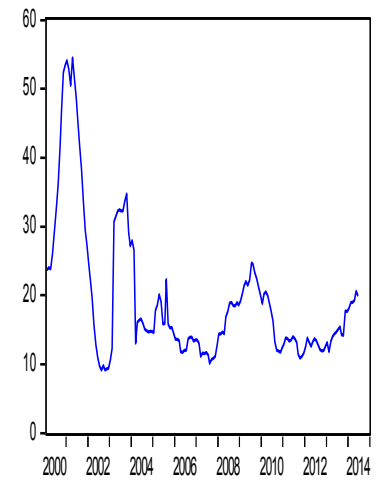

-NF_NF

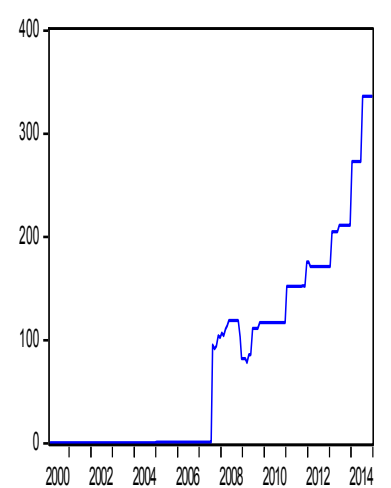

-DPEP 
Appendix 2. Estimated VAR Results

\begin{tabular}{|c|c|c|c|c|c|c|c|c|c|c|c|c|}
\hline & INF & F_NFF & EXHP & EXHD & EXCHE & EX & DPETP & LM1 & NF_INF & W & W_ENER_P & WFP \\
\hline $\operatorname{INF}(-1)$ & $\begin{array}{l}1.217588 \\
(0.08447) \\
{[14.4152]}\end{array}$ & $\begin{array}{l}0.420238 \\
(0.06561) \\
{[6.40555]}\end{array}$ & $\begin{array}{c}-0.002686 \\
(0.00444) \\
{[-0.00532]}\end{array}$ & $\begin{array}{l}-0.000101 \\
(0.00074) \\
{[-0.13623]}\end{array}$ & $\begin{array}{l}-0.012246 \\
(0.00320) \\
{[-3.82528]}\end{array}$ & $\begin{array}{c}-5.39 E-05 \\
(0.00015) \\
{[-0.35028]}\end{array}$ & $\begin{array}{c}-0.408353 \\
(0.47041) \\
{[-0.86808]}\end{array}$ & $\begin{array}{l}0.000129 \\
(0.00354) \\
{[0.03656]}\end{array}$ & $\begin{array}{l}1.260831 \\
(0.06923) \\
{[18.2125]}\end{array}$ & $\begin{array}{l}-0.131406 \\
(0.15314) \\
{[-0.85808]}\end{array}$ & $\begin{array}{l}0.106735 \\
(0.24315) \\
{[0.43897]}\end{array}$ & $\begin{array}{c}-0.010545 \\
(0.03173) \\
{[-0.33231]}\end{array}$ \\
\hline $\mathbb{N} \mathbb{N F}(-2)$ & $\begin{array}{l}-0.323222 \\
(0.13255) \\
{[-2.43844]}\end{array}$ & $\begin{array}{r}-0.106301 \\
(0.10296) \\
{[-1.03249]}\end{array}$ & $\begin{array}{l}0.010454 \\
(0.00696) \\
{[1.50112]}\end{array}$ & $\begin{array}{l}0.000756 \\
(0.00117) \\
{[0.64758]}\end{array}$ & $\begin{array}{l}0.014720 \\
(0.00502) \\
{[2.92997]}\end{array}$ & $\begin{array}{c}1.77 E-05 \\
(0.00024) \\
{[0.07315]}\end{array}$ & $\begin{array}{l}0.730223 \\
(0.73822) \\
{[0.98916]}\end{array}$ & $\begin{array}{r}-0.000759 \\
(0.00555) \\
{[-0.13670]}\end{array}$ & $\begin{array}{c}-1.000237 \\
(0.10864) \\
{[-9.20672]}\end{array}$ & $\begin{array}{l}0.083116 \\
(0.24032) \\
{[0.34585]}\end{array}$ & $\begin{array}{l}0.403098 \\
(0.38158) \\
{[1.05640]}\end{array}$ & $\begin{array}{l}0.029019 \\
(0.04980) \\
{[0.58274]}\end{array}$ \\
\hline$F_{-}$INF $(-1)$ & $\begin{array}{l}0.130504 \\
(0.10772) \\
{[1.21151]}\end{array}$ & $\begin{array}{l}0.983363 \\
(0.08367) \\
{[11.7532]}\end{array}$ & $\begin{array}{c}-0.011032 \\
(0.00566) \\
{[-1.94926]}\end{array}$ & $\begin{array}{l}0.001864 \\
(0.00095) \\
{[1.96478]}\end{array}$ & $\begin{array}{l}0.001428 \\
(0.00408) \\
{[0.34978]}\end{array}$ & $\begin{array}{l}0.000272 \\
(0.00020) \\
{[1.38417]}\end{array}$ & $\begin{array}{c}0.626134 \\
(0.59992) \\
{[1.04369]}\end{array}$ & $\begin{array}{l}0.000547 \\
(0.00451) \\
{[0.12117]}\end{array}$ & $\begin{array}{l}-0.119525 \\
(0.08829) \\
{[-1.35380]}\end{array}$ & $\begin{array}{l}0.615240 \\
(0.19530) \\
{[3.15022]}\end{array}$ & $\begin{array}{r}-0.419496 \\
(0.31009) \\
{[-1.35282]}\end{array}$ & $\begin{array}{l}0.021294 \\
(0.04047) \\
{[0.52620]}\end{array}$ \\
\hline$F_{-}$_NFF(-2) & $\begin{array}{c}-0.181524 \\
(0.10170) \\
{[-1.178496]}\end{array}$ & $\begin{array}{r}-0.282281 \\
(0.07899) \\
{[-3.57369]}\end{array}$ & $\begin{array}{l}0.004379 \\
(0.00534) \\
{[0.81966]}\end{array}$ & $\begin{array}{l}-0.002013 \\
(0.00090) \\
{[-2.24761]}\end{array}$ & $\begin{array}{l}-0.002287 \\
(0.00385) \\
{[-0.59343]}\end{array}$ & $\begin{array}{r}-0.000281 \\
(0.00019) \\
{[-1.51581]}\end{array}$ & $\begin{array}{c}-0.447241 \\
(0.56637) \\
{[-0.78966]}\end{array}$ & $\begin{array}{c}1.54 E-05 \\
(0.00426) \\
{[0.00362]}\end{array}$ & $\begin{array}{l}0.014031 \\
(0.08335) \\
{[0.16833]}\end{array}$ & $\begin{array}{c}-0.785542 \\
(0.18438) \\
{[-4.26047]}\end{array}$ & $\begin{array}{r}-0.316918 \\
(0.29275) \\
{[-1.08255]}\end{array}$ & $\begin{array}{c}-0.075697 \\
(0.03821) \\
{[-1.98133]}\end{array}$ \\
\hline EXHP(-1) & $\begin{array}{r}-1.232841 \\
(1.64277) \\
{[-0.75047]}\end{array}$ & $\begin{array}{c}-6.329017 \\
(1.27596) \\
{[-4.96021]}\end{array}$ & $\begin{array}{l}0.434094 \\
(0.08631) \\
{[5.02962]}\end{array}$ & $\begin{array}{l}-0.030599 \\
(0.01447) \\
{[-2.11451]}\end{array}$ & $\begin{array}{l}0.033519 \\
(0.06226) \\
{[0.53834]}\end{array}$ & $\begin{array}{c}-0.002022 \\
(0.00299) \\
{[-0.07520]}\end{array}$ & $\begin{array}{l}-0.035088 \\
(9.14901) \\
{[-0.00384]}\end{array}$ & $\begin{array}{l}-0.030829 \\
(0.06884) \\
{[-0.44782]}\end{array}$ & $\begin{array}{l}0.355224 \\
(1.34643) \\
{[0.26383]}\end{array}$ & $\begin{array}{r}-5.025046 \\
(2.97840) \\
{[-1.68716]}\end{array}$ & $\begin{array}{l}4.609992 \\
(4.72899) \\
{[0.97484]}\end{array}$ & $\begin{array}{r}-1.082975 \\
(0.61715) \\
{[-1.75479]}\end{array}$ \\
\hline EXHP(-2) & $\begin{array}{l}1.503230 \\
(1.58358) \\
{[0.94926]}\end{array}$ & $\begin{array}{l}2.868315 \\
(1.22998) \\
{[2.33199]}\end{array}$ & $\begin{array}{c}-0.001906 \\
(0.08320) \\
{[-0.02291]}\end{array}$ & $\begin{array}{l}-0.029246 \\
(0.01395) \\
{[-2.09657]}\end{array}$ & $\begin{array}{l}-0.021577 \\
(0.06002) \\
{[-0.35950]}\end{array}$ & $\begin{array}{r}-0.005311 \\
(0.00289) \\
{[-1.83970]}\end{array}$ & $\begin{array}{l}6.287503 \\
(8.81937) \\
{[0.71292]}\end{array}$ & $\begin{array}{l}0.053057 \\
(0.06636) \\
{[0.79951]}\end{array}$ & $\begin{array}{l}-0.114141 \\
(1.29792) \\
{[-0.08794]}\end{array}$ & $\begin{array}{l}6.196484 \\
(2.87109) \\
{[2.15823]}\end{array}$ & $\begin{array}{c}-11.82303 \\
(4.55861) \\
{[-2.59356]}\end{array}$ & $\begin{array}{l}0.396921 \\
(0.59492) \\
{[0.66719]}\end{array}$ \\
\hline $\operatorname{EXHD}(-1)$ & $\begin{array}{l}2.941409 \\
(10.5877) \\
{[0.27781]}\end{array}$ & $\begin{array}{c}-4.092092 \\
(8.22359) \\
{[-0.49760]}\end{array}$ & $\begin{array}{l}0.465738 \\
(0.55625) \\
{[0.83727]}\end{array}$ & $\begin{array}{r}1.044169 \\
(0.09326) \\
{[11.1957]}\end{array}$ & $\begin{array}{l}0.660848 \\
(0.40129) \\
{[1.64682]}\end{array}$ & $\begin{array}{l}0.924973 \\
(0.01930) \\
{[47.9265]}\end{array}$ & $\begin{array}{c}3.795236 \\
(58.9657) \\
{[0.06436]}\end{array}$ & $\begin{array}{l}-1.134274 \\
(0.44369) \\
{[-2.55643]}\end{array}$ & $\begin{array}{l}6.952574 \\
(8.67781) \\
{[0.80119]}\end{array}$ & $\begin{array}{l}27.60762 \\
(19.1959) \\
{[1.43820]}\end{array}$ & $\begin{array}{c}-19.49900 \\
(30.4785) \\
{[-0.63976]}\end{array}$ & $\begin{array}{c}-3.397159 \\
(3.97757) \\
{[-0.85408]}\end{array}$ \\
\hline EXHD(-2) & $\begin{array}{r}-46.73226 \\
(43.3703) \\
{[-1.07752]}\end{array}$ & $\begin{array}{c}-16.22586 \\
(33.6862) \\
{[-0.48168]}\end{array}$ & $\begin{array}{r}-2.768359 \\
(2.27858) \\
{[-1.21495]}\end{array}$ & $\begin{array}{l}0.201665 \\
(0.38204) \\
{[0.52786]}\end{array}$ & $\begin{array}{r}-1.357688 \\
(1.64379) \\
{[-0.82595]}\end{array}$ & $\begin{array}{c}-0.079345 \\
(0.07906) \\
{[-1.00363]}\end{array}$ & $\begin{array}{c}179.5836 \\
(241.541) \\
{[0.74349]}\end{array}$ & $\begin{array}{l}0.773598 \\
(1.81750) \\
{[0.42564]}\end{array}$ & $\begin{array}{l}30.41473 \\
(35.5468) \\
{[0.85562]}\end{array}$ & $\begin{array}{l}63.46287 \\
(78.6320) \\
{[0.80709]}\end{array}$ & $\begin{array}{l}217.7964 \\
(124.849) \\
{[1.74448]}\end{array}$ & $\begin{array}{l}31.87194 \\
(16.2933) \\
{[1.95614]}\end{array}$ \\
\hline EXCHE $(-1)$ & $\begin{array}{c}5.173084 \\
(2.28926) \\
{[2.25972]}\end{array}$ & $\begin{array}{l}4.468059 \\
(1.77810) \\
{[2.51283]}\end{array}$ & $\begin{array}{l}0.092245 \\
(0.12027) \\
{[0.76696]}\end{array}$ & $\begin{array}{c}0.043962 \\
(0.02017) \\
{[2.18004]}\end{array}$ & $\begin{array}{l}0.540928 \\
(0.08677) \\
{[6.23433]}\end{array}$ & $\begin{array}{l}0.003435 \\
(0.00417) \\
{[0.82309]}\end{array}$ & $\begin{array}{l}21.83989 \\
(12.7495) \\
{[1.71300]}\end{array}$ & $\begin{array}{l}0.017160 \\
(0.09594) \\
{[0.17887]}\end{array}$ & $\begin{array}{l}2.505704 \\
(1.87631) \\
{[1.33544]}\end{array}$ & $\begin{array}{l}0.417502 \\
(4.15052) \\
{[0.10059]}\end{array}$ & $\begin{array}{l}0.898756 \\
(6.59003) \\
{[0.13638]}\end{array}$ & $\begin{array}{l}0.655884 \\
(0.86003) \\
{[0.76263]}\end{array}$ \\
\hline EXCHE(-2) & $\begin{array}{r}-4.231585 \\
(2.26456) \\
{[-1.86861]}\end{array}$ & $\begin{array}{l}-0.623418 \\
(1.75891) \\
{[-0.35443]}\end{array}$ & $\begin{array}{l}0.230616 \\
(0.11898) \\
{[1.93835]}\end{array}$ & $\begin{array}{c}-0.001841 \\
(0.01995) \\
{[-0.09230]}\end{array}$ & $\begin{array}{l}0.118163 \\
(0.08583) \\
{[1.37671]}\end{array}$ & $\begin{array}{l}0.000985 \\
(0.00413) \\
{[0.23864]}\end{array}$ & $\begin{array}{l}-9.864792 \\
(12.6119) \\
{[-0.78218]}\end{array}$ & $\begin{array}{c}-0.091712 \\
(0.09490) \\
{[-0.96641]}\end{array}$ & $\begin{array}{l}1.035997 \\
(1.85606) \\
{[0.55817]}\end{array}$ & $\begin{array}{l}-8.389961 \\
(4.10574) \\
{[-2.04347]}\end{array}$ & $\begin{array}{l}1.039157 \\
(6.51893) \\
{[0.15941]}\end{array}$ & $\begin{array}{r}-1.277157 \\
(0.85075) \\
{[-1.50122]}\end{array}$ \\
\hline EXX(-1) & $\begin{array}{l}47.69097 \\
(46.5717) \\
{[1.02403]}\end{array}$ & $\begin{array}{c}23.79586 \\
(36.1728) \\
{[0.65784]}\end{array}$ & $\begin{array}{c}2.738694 \\
(2.44678) \\
{[1.11931]}\end{array}$ & $\begin{array}{l}-0.230658 \\
(0.41024) \\
{[-0.56225]}\end{array}$ & $\begin{array}{c}1.289217 \\
(1.76513) \\
{[0.73038]}\end{array}$ & $\begin{array}{l}0.219168 \\
(0.08489) \\
{[2.58169]}\end{array}$ & $\begin{array}{r}-198.9386 \\
(259.370) \\
{[-0.76701]}\end{array}$ & $\begin{array}{l}1.111228 \\
(1.95166) \\
{[0.56938]}\end{array}$ & $\begin{array}{r}-44.65857 \\
(38.1707) \\
{[-1.16997]}\end{array}$ & $\begin{array}{r}-79.24284 \\
(84.4363) \\
{[-0.93849]}\end{array}$ & $\begin{array}{r}-219.1819 \\
(134.065) \\
{[-1.63490]}\end{array}$ & $\begin{array}{l}-20.62551 \\
(17.4960) \\
{[-1.17887]}\end{array}$ \\
\hline EX(-2) & $\begin{array}{c}-3.079402 \\
(9.50721) \\
{[-0.32390]}\end{array}$ & $\begin{array}{l}1.494774 \\
(7.38435) \\
{[0.20242]}\end{array}$ & $\begin{array}{l}0.092590 \\
(0.49949) \\
{[0.18537]}\end{array}$ & $\begin{array}{r}-0.088871 \\
(0.08375) \\
{[-1.06119]}\end{array}$ & $\begin{array}{r}-0.360800 \\
(0.36034) \\
{[-1.00129]}\end{array}$ & $\begin{array}{r}-0.058120 \\
(0.01733) \\
{[-3.35368]}\end{array}$ & $\begin{array}{c}-7.700388 \\
(52.9481) \\
{[-0.14543]}\end{array}$ & $\begin{array}{c}-0.659977 \\
(0.39841) \\
{[-1.65651]}\end{array}$ & $\begin{array}{c}4.362804 \\
(7.79222) \\
{[0.55989]}\end{array}$ & $\begin{array}{l}4.753398 \\
(17.2369) \\
{[0.27577]}\end{array}$ & $\begin{array}{l}23.16755 \\
(27.3681) \\
{[0.84652]}\end{array}$ & $\begin{array}{r}-3.593952 \\
(3.57165) \\
{[-1.00624]}\end{array}$ \\
\hline DPETP(-1) & $\begin{array}{l}-0.000109 \\
(0.01619)\end{array}$ & $\begin{array}{l}0.000176 \\
(0.01257)\end{array}$ & $\begin{array}{l}0.000613 \\
(0.00085)\end{array}$ & $\begin{array}{l}0.000108 \\
(0.00014)\end{array}$ & $\begin{array}{l}0.000681 \\
(0.00061)\end{array}$ & $\begin{array}{l}-2.88 E-05 \\
(3.0 E-05)\end{array}$ & $\begin{array}{l}0.774512 \\
(0.09015)\end{array}$ & $\begin{array}{l}-7.52 E-05 \\
(0.00068)\end{array}$ & $\begin{array}{l}0.007663 \\
(0.01327)\end{array}$ & $\begin{array}{l}0.012588 \\
(0.02935)\end{array}$ & $\begin{array}{l}0.122770 \\
(0.04660)\end{array}$ & $\begin{array}{l}0.007862 \\
(0.00608)\end{array}$ \\
\hline
\end{tabular}




\begin{tabular}{|c|c|c|c|c|c|c|c|}
\hline \multirow[t]{3}{*}{ DPETP(-2) } & 0.011067 & 0.011286 & -0.001286 & $-1.12 \mathrm{E}-05$ & $3.89 E-05$ & $1.17 E-05$ & -0.021803 \\
\hline & $(0.01606)$ & $(0.01248)$ & $(0.00084)$ & $(0.00014)$ & $(0.00061)$ & $(2.9 E-05)$ & $(0.08947)$ \\
\hline & [0.68894] & [0.90455] & {$[-1.52324]$} & {$[-0.07890]$} & {$[0.06394]$} & [0.40022] & {$[-0.24370]$} \\
\hline \multirow[t]{3}{*}{ LM1(-1) } & -3.645301 & 1.908035 & 0.575461 & 0.027978 & 0.039742 & 0.000385 & -6.761464 \\
\hline & $(2.12260)$ & $(1.64865)$ & $(0.11152)$ & $(0.01870)$ & $(0.08045)$ & $(0.00387)$ & $(11.8213)$ \\
\hline & {$[-1.71737]$} & [1.15733] & [5.16030] & [1.49632] & [0.49399] & [0.09947] & {$[-0.57197]$} \\
\hline \multirow[t]{3}{*}{$\operatorname{LM} 1(-2)$} & 2.687285 & -0.310369 & -0.476560 & -0.017283 & 0.076680 & 0.000910 & -13.07885 \\
\hline & (2.26902) & (1.76237) & $(0.11921)$ & $(0.01999)$ & $(0.08600)$ & $(0.00414)$ & (12.6367) \\
\hline & [1.18434] & {$[-0.17611]$} & {$[-3.99768]$} & {$[-0.86471]$} & {$[0.89164]$} & [0.22005] & [-1.03499] \\
\hline \multirow[t]{3}{*}{$N F_{-}$INF(-1) } & 0.118246 & -0.217304 & -0.002644 & -0.000123 & 0.004492 & $-1.83 E-06$ & -0.195653 \\
\hline & $(0.08318)$ & $(0.06461)$ & $(0.00437)$ & $(0.00073)$ & $(0.00315)$ & $(0.00015)$ & $(0.46325)$ \\
\hline & [1.42159] & {$[-3.36353]$} & {$[-0.60513]$} & {$[-0.16762]$} & [1.42490] & {$[-0.01208]$} & {$[-0.42235]$} \\
\hline \multirow[t]{3}{*}{$N F$ INF(-2) } & -0.102180 & 0.072335 & -0.001852 & -0.000462 & -0.005574 & $7.30 \mathrm{E}-06$ & -0.123726 \\
\hline & $(0.06247)$ & $(0.04852)$ & $(0.00328)$ & $(0.00055)$ & $(0.00237)$ & $(0.00011)$ & $(0.34788)$ \\
\hline & [-1.63579] & [1.49091] & {$[-0.56434]$} & {$[-0.84001]$} & {$[-2.35442]$} & {$[0.06410]$} & {$[-0.35565]$} \\
\hline \multirow[t]{3}{*}{$W(-1)$} & -0.030304 & 0.164618 & 0.006783 & 0.000646 & -0.002685 & 0.000238 & 0.047591 \\
\hline & $(0.05356)$ & $(0.04160)$ & $(0.00281)$ & $(0.00047)$ & $(0.00203)$ & $(9.8 \mathrm{E}-05)$ & $(0.29827)$ \\
\hline & {$[-0.56583]$} & [3.95735] & [2.41063] & [1.36837] & {$[-1.32260]$} & [2.43629] & [0.15956] \\
\hline \multirow[t]{3}{*}{$W(-2)$} & -0.005630 & -0.201101 & -0.009763 & $-9.43 E-05$ & 0.001516 & -0.000311 & -0.121139 \\
\hline & $(0.05509)$ & $(0.04279)$ & $(0.00289)$ & $(0.00049)$ & $(0.00209)$ & $(0.00010)$ & $(0.30682)$ \\
\hline & {$[-0.10219]$} & {$[-4.69974]$} & {$[-3.37300]$} & {$[-0.19434]$} & [0.72591] & {$[-3.09342]$} & {$[-0.39483]$} \\
\hline \multirow[t]{3}{*}{ W_ENER_P(-1) } & 0.009716 & -0.020505 & 0.004851 & -0.000507 & 0.003125 & $4.56 \mathrm{E}-07$ & 0.168293 \\
\hline & $(0.02598)$ & $(0.02018)$ & $(0.00136)$ & $(0.00023)$ & $(0.00098)$ & $(4.7 E-05)$ & $(0.14466)$ \\
\hline & {$[0.37403]$} & {$[-1.01632]$} & [3.55474] & {$[-2.21440]$} & [3.17368] & [0.00963] & [1.16333] \\
\hline \multirow[t]{3}{*}{ W_ENER_P(-2) } & -0.010692 & 0.036751 & -0.002326 & 0.000295 & -0.003271 & $3.87 E-05$ & -0.084582 \\
\hline & $(0.02592)$ & $(0.02013)$ & $(0.00136)$ & $(0.00023)$ & $(0.00098)$ & $(4.7 E-05)$ & $(0.14433)$ \\
\hline & {$[-0.41256]$} & [1.82580] & [-1.70843] & [1.29315] & {$[-3.33021]$} & {$[0.81938]$} & {$[-0.586003]$} \\
\hline \multirow[t]{3}{*}{ WFP(-1) } & -0.033397 & -0.290409 & 0.006690 & -0.004002 & -0.002616 & -0.001016 & 3.191161 \\
\hline & $(0.23967)$ & $(0.18615)$ & $(0.01259)$ & $(0.00211)$ & $(0.00908)$ & $(0.00044)$ & $(1.33478)$ \\
\hline & {$[-0.13935]$} & {$[-1.56005]$} & [0.53131] & {$[-1.89545]$} & {$[-0.28795]$} & {$[-2.32565]$} & [2.39078] \\
\hline \multirow[t]{3}{*}{ WFP(-2) } & 0.030652 & 0.177285 & -0.009903 & 0.004165 & 0.002418 & 0.001019 & -2.302358 \\
\hline & $(0.23874)$ & $(0.18543)$ & $(0.01254)$ & $(0.00210)$ & $(0.00905)$ & $(0.00044)$ & $(1.32960)$ \\
\hline & [0.12839] & {$[0.95606]$} & {$[-0.78951]$} & [1.98058] & {$[0.26724]$} & [2.34203] & [-1.73161] \\
\hline \multirow[t]{3}{*}{$C$} & 8.343908 & 2.458057 & -0.189110 & 0.016426 & -0.610175 & -0.006535 & 24.07326 \\
\hline & $(5.31754)$ & $(4.13019)$ & $(0.27937)$ & $(0.04684)$ & $(0.20154)$ & $(0.00969)$ & $(29.6148)$ \\
\hline & [1.56913] & [0.59514] & {$[-0.67691]$} & {$[0.35068]$} & {$[-3.02754]$} & {$[-0.67423]$} & [0.81288] \\
\hline R-squared & 0.967499 & 0.969594 & 0.979494 & 0.998646 & 0.990507 & 0.999941 & 0.984957 \\
\hline Adj. R-squared & 0.961545 & 0.964024 & 0.975737 & 0.998398 & 0.988767 & 0.999931 & 0.982201 \\
\hline Sum sq. resids & 349.9780 & 211.1346 & 0.966016 & 0.027156 & 0.502747 & 0.001163 & 10855.14 \\
\hline S.E. equation & 1.634499 & 1.269533 & 0.085873 & 0.014398 & 0.061950 & 0.002979 & 9.102950 \\
\hline F-statistic & 162.4865 & 174.0582 & 260.7214 & 4026.500 & 569.5053 & 93094.74 & 357.3922 \\
\hline Log likelihood & -284.3795 & -244.9603 & 175.2312 & 453.8134 & 226.1725 & 699.5674 & .552 .2724 \\
\hline Akaike AIC & 3.966404 & 3.461030 & -1.926041 & -5.497608 & -2.579135 & -8.648300 & 7.400928 \\
\hline Schwarz SC & 4.455163 & 3.949789 & -1.437282 & -5.008849 & -2.090376 & -8.159541 & 7.889687 \\
\hline Mean dependent & 16.36994 & 13.49353 & 1.810064 & 1.093846 & 1.395897 & 1.084521 & 57.41128 \\
\hline
\end{tabular}


Appendix 3. Residual Graphs of the VAR equations

IN Residds

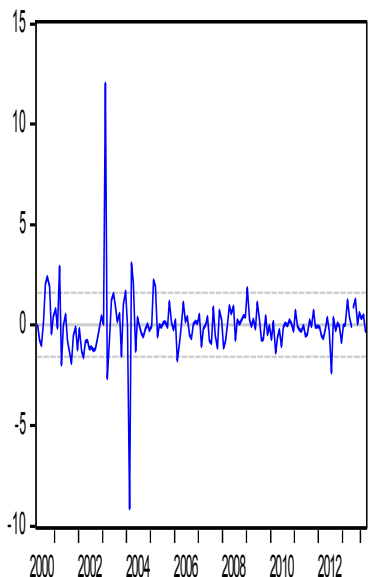

WResiddas

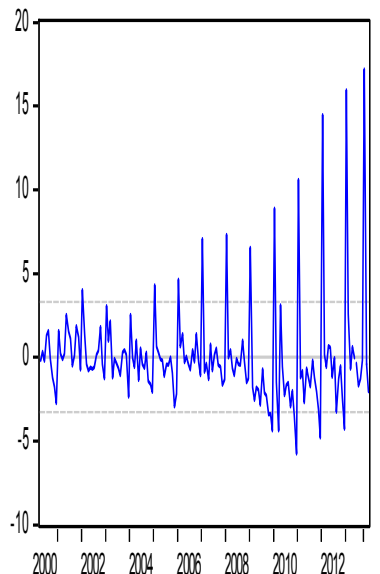

EX Resiclals

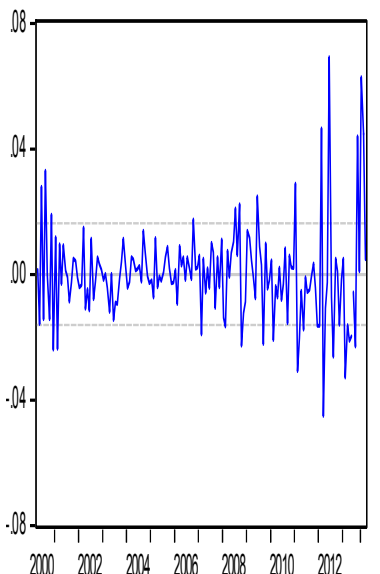

LGDP__EAR Residuds

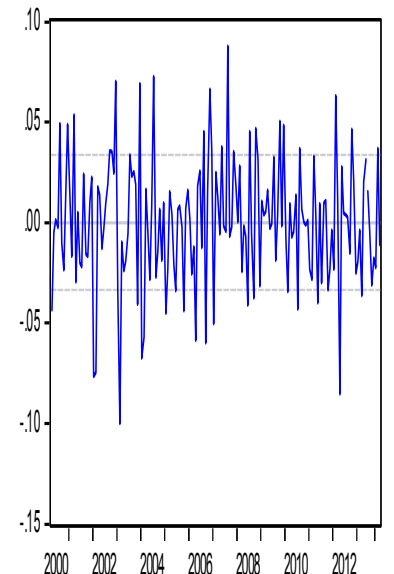

WFP Residdas

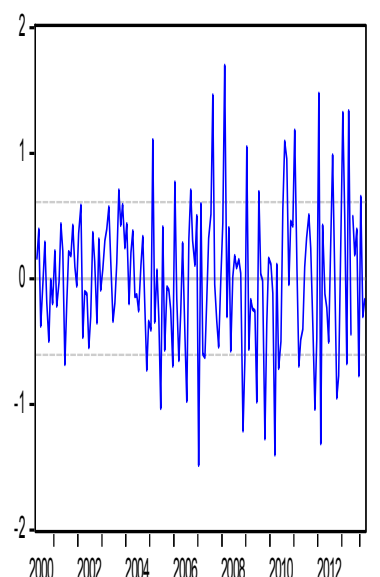

F_INF Reiddals

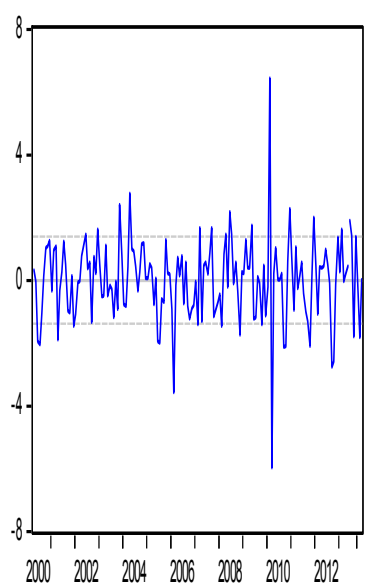

LMM Rescidals

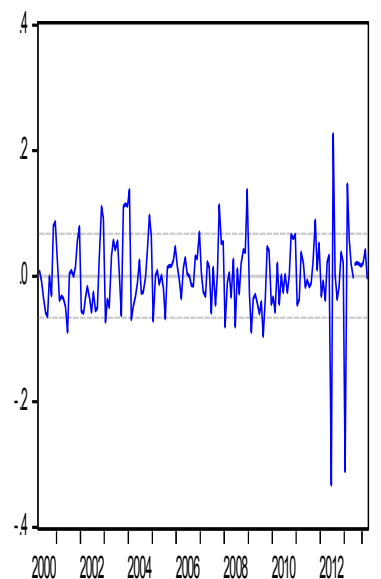

WENER P Residals

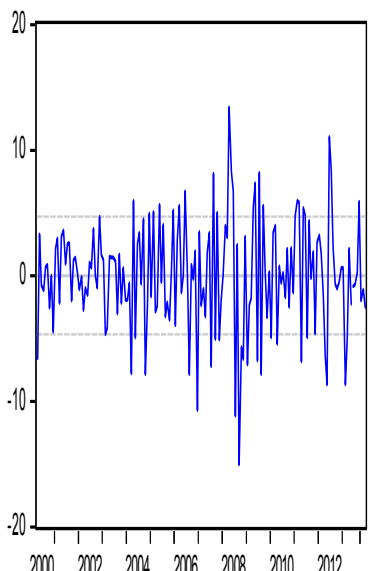

$20002002 \quad 20042006200820002012$
NF-NF Residds

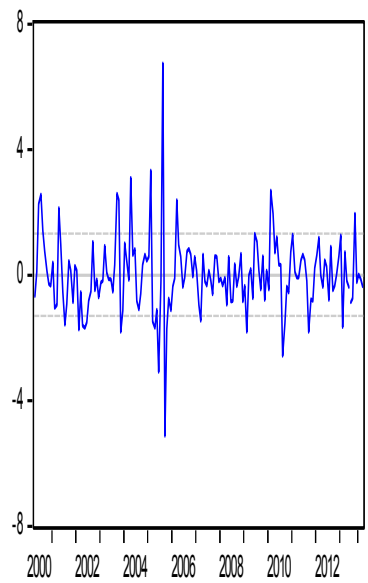

DPETP Residals

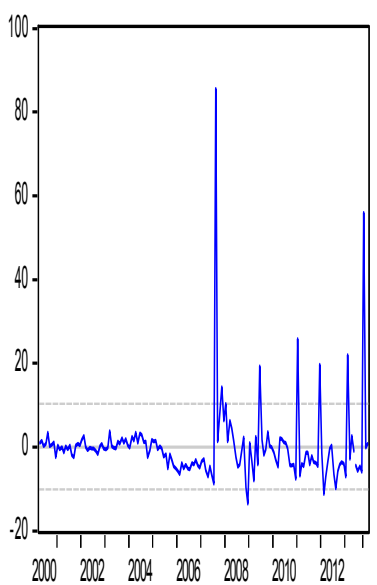




\section{Copyright Disclaimer}

Copyright for this article is retained by the author(s), with first publication rights granted to the journal. This is an open-access article distributed under the terms and conditions of the Creative Commons Attribution license (http://creativecommons.org/licenses/by/3.0/). 